Here in Our

Auschwitz and

Other Stories 
This page intentionally left blank 


\section{Here in Our}

\section{Auschwitz and}

Other Stories

\section{TADEUSZ BOROWSK I}

FOREWORD BY TIMOTHY SNYDER

TRANSLATED FROM THE POLISH

BY MADELINE G. LEVINE

YALE UNIVERSITY PRESS INEW HAVEN \& LONDON 
The Margellos World Republic of Letters is dedicated to making literary works from around the globe available in English through translation. It brings to the Englishspeaking world the work of leading poets, novelists, essayists, philosophers, and playwrights from Europe, Latin America, Africa, Asia, and the Middle East to stimulate international discourse and creative exchange.

Copyright (C) 2021 by Yale University. Foreword copyright (C) 2021 by Timothy Snyder. All rights reserved.

This book may not be reproduced, in whole or in part, including illustrations, in any form (beyond that copying permitted by Sections 107 and 108 of the U.S. Copyright Law and except by reviewers for the public press), without written permission from the publishers.

Yale University Press books may be purchased in quantity for educational, business, or promotional use. For information, please email sales.press@yale.edu (U.S. office) or sales@yaleup.co.uk (U.K. office).

Set in Electra type by Newgen North America. Printed in the United States of America.

Library of Congress Control Number: 2020951855

ISBN 978-0-300-1169o-8 (hardcover : alk. paper)

A catalogue record for this book is available from the British Library.

This paper meets the requirements of ANSI/NISO Z39.48-1992 (Permanence of Paper). 10987654321 